ERIKson, D. (1954). J. gen. Microbiol. 11, 198-208

\title{
Factors Promoting Cell Division in a 'Soft' Mycelial Type of Nocardia: Nocardia turbata n.sp.
}

\author{
BY DAGNY ERIKSON \\ Bacteriology Department, University of Aberdeen
}

\begin{abstract}
SUMMARY: Various methods of preparing microcultures with liquids (hanging-drop) and solids (collodion, cellophan, agar) were compared with respect to the mode of growth of the test organism on a complex nutrient substrate. Cell division was promoted in general by lower temperatures, by ageing, by lack of humidity in solid cultures, by the action of surface tension operating in the more convex droplets, and by the addition of surface-active agents to liquid media. By varying the carbon sources in chemically defined media it was found that starch, glycogen, and to some extent glucose, favoured filamentation, i.e. retarded or inhibited cell division, in comparison with a considerable variety of other sugars. Of the nitrogenous sources, nitrate resulted in relatively poor growth mainly composed of mycelial aggregates that later exhibited cell division to the extreme limits; ammonium salts yielded more profuse filamentous growth with less subdivision; certain single amino acids induced a more uniform development of short rods; while casein hydrolysate commonly produced a variety of cell elements showing subdivision in all stages. Single cell isolates were used throughout, and the mode of growth was studied by means of phase-contrast and electron microscopy.
\end{abstract}

A cultural description of the test organism, Nocardia turbata, n.sp. is given at the end of the paper.

The indispensable criterion of the actinomycetes as a family is the formation of a branching mycelium. The outstanding character of the genus Nocardia is the fragmentation of this initial mycelium into short or long elements: branching, filamentous, bacillary or coccoid. The simplest way of subdividing this genus is in accordance with: $(a)$ the rapidity or otherwise with which spontaneous fragmentation takes place; $(b)$ the degree, partial or complete, to which cell division is carried on with ensuing breaking-up of the mycelium. This is, in fact, the basis of the morphological classifications of Ørskov (1923) and Jensen (1931), and of the derivative scheme proposed by Waksman \& Henrici (1943) and adopted in the 6th edition of Bergey's Manual (1948).

A 'soft' mycelial type of nocardia is, therefore, one in which cell division proceeds more or less rapidly and to the extreme limits. As a direct consequence of this fragmentation, such a strain exhibits in liquid cultures some degree of turbidity (as against the characteristic clarity shown by actinomycetes with structurally intact mycelium), while on solid substrates massive sowings result in smooth readily emulsifiable growth which entirely resembles that of many ordinary bacteria. The fragmented cells themselves often retain $V$ - and Y-forms similar to those of corynebacteria. Indeed, it is because of the systematically interesting position-at the borderline between eubacteria and actinomycetes - that it is of value to study the ways in which cell division takes place within the transient chains and branching filaments of these short-lived mycelial aggregates. 


\section{ORGANISM}

The test organism used here has several interesting features:

(1) On most suitable solid media single cells develop into small mycelia showing true branching, which are entirely characteristic of actinomycetes in general (Pl. 1, fig. 1). These fragment rapidly on poor substrates (Pl. 1, fig. 2), while on rich complex media such as nutrient agar the peripheral filaments of well-spaced colonies may be seen branching and radiating into the depths of the agar even after 2-4 weeks of growth at room temperature. It is therefore not possible to doubt that this organism is an actinomycete, as is sometimes possible with very 'soft' species of Nocardia. On the other hand, the cell mass of even such aged single colonies is of a pasty texture, and can readily be removed from the medium and the component cells smoothly dispersed in water. Moreover, by the use of soft agar and massive inocula, moist smeary growths can be produced which look entirely bacterial, while in liquid cultures turbidity is the rule.

(2) The phenomenon of fragmentation is made evident in more than one way. (a) By the transformation of almost the entire central mass of the growth on solid substrates into bacillary cells of varying lengths (Pl. 1, figs. 2, 4), which may show 'slipping branching' (PI. 2, fig. 11), giving rise to 'palisade formation' (Pl. 2, fig. 15); or into coccoid cells which in certain liquid or semisolid nutrients may cohere almost like staphylococci (Pl. 1, fig. 5); or into a mixture of rods and 'cocci' (Pl. 1, fig. 3; Pl. 2, fig. 17). (b) By the varying degrees of motility shown under different circumstances by many of these polymorphous cells. So far motility has been reported among the actinomycetes only within the genus Nocardia (Topping, 1937; Ørskov, 1938). The organism studied here is one (no. 27) isolated by Dr Ørskov from Danish soil, and kindly sent to me by him. It produces an insoluble yellow-green pigment on protein-containing media, and is clearly allied to the other yellow- or greenpigmented 'soft' mycelial forms such as $N$. flava, $N$. viridis and $N$. citrea (see also Jensen, 1953). It agrees with these non-paraffin-utilizing species in having non-acid-fast and in general weakly refractile cells. It differs from them in the production of 'cocci', which are often more highly refractile than the filamentous cells, and above all by the property of motility. These are constitutional differences, which appear to merit separation by species. The specific name turbata (Lat.= restless, troubled) is proposed, and a cultural description of the organism is given under the name Nocardia turbata $\mathbf{n}$.sp.

In the course of these studies it was soon realized that while in all circumstances cell division constantly precedes motility, it was not necessarily followed by motility. Cell division accompanied by fragmentation could and frequently did take place without any subsequent motility on the part of any of the variously shaped cell elements. The conditions which favoured motility could therefore to some extent be considered separately; this will be done in a future communication. In the present work the emphasis has been placed upon cell division, while noting the presence or absence of motility.

In view of the morphological diversity to be found within this species, 
twelve single-cell isolates were prepared by means of the de Fonbrune micromanipulator (for details see Erikson \& Masson, 1954). Stock cultures of these pure line strains were maintained on nutrient (peptone + Lab Lemco+ Marmite) agar at room temperature. Aqueous suspensions of washed cells from such nutrient agar slopes were employed as inocula, and the cells of two different isolates were used in every experiment.

\section{METHODS}

Liquid media. The growth of Nocardia turbata in a variety of media was studied in small volumes ( $2 \mathrm{ml}$. in 4 in. $\times \frac{1}{2}$ in. test-tubes), which gave good aeration favouring profuse growth. At room temperature $\left(18-23^{\circ}\right)$, the optimum for the demonstration of motility and suitable for growth in general, there was little evaporation in the course of 1-2 weeks. A fairly heavy inoculum $\left(5 \times 10^{6}\right.$ cells $/ \mathrm{ml}$.) was required to establish characteristic growth in the various media within 2-6 days, the peak period of growth. This inoculum was obtained by washing the growth from a 2-day nutrient agar slope, resuspending it in $5 \mathrm{ml}$. water, spinning lightly to throw down the bulk of the mycelial fragments, and matching the suspension, containing mainly rod and coccoid elements, to a given arbitrary standard for each experiment; $0.1 \mathrm{ml}$. of the suspension was added to each tube.

The media used can be classified according to their composition as follows:

Media containing nitrogen as nitrate. A basal medium of Czapek mineral salts with sodium nitrate, to which was added: $0.5 \%(w / v)$ of fermentable sugars, occasionally $0.1 \%$ yeast extract (Yeastrel), or $0.025 \%$ of various surface active agents such as Tween 80 or Nonex 139.

Media containing nitrogen as ammonium salts. The basal Czapek mineral salt medium with ammonium phosphate, ammonium chloride, or ammonium sulphate in place of the sodium nitrate. Sugars added in the same proportion as above.

Media containing nitrogen as single amino acids. The basal Czapek mineral salt medium with a single amino acid $(0 \cdot 1 \%, w / v)$ in place of the sodium nitrate. Sugars added in the same proportion as above.

Media containing nitrogen as a mixture of amino acids. The basal Czapek mineral salt medium with $0.1 \%(\mathrm{w} / \mathrm{v})$ of an acid hydrolysate of casein (vitamin-free). Two preparations were used; one made by Allen and Hanburys Ltd., the other by Ashe Products, Ltd. Again sugars were added in the same proportion as above. In all instances the sugars were sterilized separately, added aseptically to the sterile basal media, and then briefly steamed.

Media containing nitrogen in more complex forms. These included standard nutrient broth of the same composition as the nutrient agar on which the stock cultures were maintained; and with the following additions: $5 \%$ tryptic digest of casein; $5 \%$ heart broth; $5 \%$ brain-heart infusion (Difco). Occasionally surface active agents were added to the plain broth in the proportions noted above.

The $\mathrm{pH}$ value of all media was adjusted to $\mathbf{7 \cdot 2}$.

Micro hanging-drop cultures. These were prepared according to the method 
of Webley (1953), with the modification that the spraying vessel was connected by means of a ground glass joint to a 'Quickfit' Pyrex tube $8 \times \frac{1}{2}$ in., which was then covered by a metal cap with a hole, $\frac{1}{8}$ in. diameter, drilled in the centre. The coverslip to be sprayed was inverted over this cap. All the components of this system can be sterilized separately and assembled quickly. In their passage through the relatively narrow lumen of the tubing, the droplets did not evaporate so that there was no need for a special moist chamber. Otherwise the procedure throughout was as described by Webley. The slides were examined daily by the ordinary light microscope.

Microcultures using solid media. The same dilute suspensions used for spraying the hanging-drop cultures, employing media of all the classes mentioned, were examined for the mode of growth of the cells in an agar film. In such cases the sprayed and dried slips were inverted over a plain slide bearing a drop of molten $1 \%$ agar + the basal medium, gentle pressure exerted to expel air bubbles, and the growing preparation (kept in a moist chamber) examined at daily intervals by phase-contrast microscopy. In other cases a small block of solidified medium under test was placed on the slide, which was sprayed directly with a dilute aqueous suspension of cells, or inoculated with a loop in the manner of Ørskov (1923). Where the simultaneous comparative observation of a number of preparations was required, the agar plaque method of Turner-Graff (1952) was found useful. A modification was made as regards inoculation in that the Petri dish containing the separate agar plaques was inverted over the spray, and each plaque sprayed in turn. Individual colonial development could be followed in these cases.

In addition, there was always available material of varying ages resulting from the sowing of nutrient agar slopes for suspensions, and the plating out of these suspensions as a check for purity.

Microcultures on cellophan and collodion membranes. To the advantages of clarity of observation and freedom from contaminating medium noted by many workers when a sheet of sterile cellophan is placed between medium and organism, there must be added, in the case of the actinomycetes, the further benefits that the growths in general tend to be flattened out with a greater proportion than usual of the cells developing in the same plane, while individual cells show a higher degree of elongation. These observations were first made by Lentze (1938) in connexion with the anaerobic actinomycetes, and have been repeatedly confirmed by the author for all groups of actinomycetes (Erikson, 1940, 1947, 1949, 1952).

Duplicates of the microcultures on agar plaques were prepared by placing circles of sterile cellophan over the plaques, incubating overnight at $30^{\circ}$ to test for sterility, and then spraying the cellophan surface of each plaque in turn. The resultant growth was used for both comparative observation and as a source of clean cells for electron micrographs (see Pl. 2, figs. 14-16). When pictures of cells actually growing on a collodion membrane were wanted, it was found helpful to support the membrane on small squares of cellophan and so interpose two layers between substrate and growing cells. This was done by placing the cellophan square on the S-shaped end of a bent glass rod and 
gently inserting it under the water on whose surface the collodion membrane had been poured in the usual way. When the rough margins of the membrane had been trimmed away with a needle, the collodion + cellophan square could be treated as a single unit and sterilized by steaming. It was then placed over a hollow ground slide, the cavity of which had been filled with a suitable solid medium, incubated in a moist chamber to test for sterility, and sprayed as above. After growth the complete unit, collodion + cellophan, was picked off the medium, fixed in formalin vapour, and floated on clean water, where it was a simple matter to prise away the supporting cellophan and collect the membrane on a grid. This method gave very clean pictures (see Pl. 2, figs. 10, 11 and 13).

In certain instances a chart of the specimens on the dried grid was made on squared paper, plotting the cells in certain marked areas of the grid as seen through the $4 \mathrm{~mm}$. objective of the light microscope. Such areas could then be found in the electron microscope, and, after micrographs of suitable cells in that area had been taken, they could be compared with the appearance of the cells in the light microscope. For permanent reference both collodion and cellophan membranes bearing fixed cells could be treated as sections, floated on warm water to smooth out wrinkles, and mounted on slides smeared with $1 \%$ gelatin.

\section{RESULTS}

It will be convenient to consider first those factors of a physical or general nature that influence the cell division of Nocardia turbata. Since such factors were generally operative regardless of the nature of the medium, their activity will be examined mainly in cultures on rich complex media, unless noted to the contrary. The consistently abundant growth on the stock nutrient agar or broth allowed a ready detection of these factors.

\section{Effect of temperature}

Lower temperatures induced early cell division and fragmentation, and were essential for the demonstration of motility. Thus, Pl. 1, fig. 1, represents the characteristic filamentous mycelial growth resulting from $24 \mathrm{hr}$. of incubation at $30^{\circ}$, while duplicate sets incubated for the same time at $20^{\circ}$ constantly showed a greater or lesser degree of cell division and fragmentation (Pl. 1, fig. 2). Although the growth in Pl. 1, fig. 2, is an older growth on a poorer medium (soil extract agar), the way in which the subdivision of the internal cell-mass of the microcolony has proceeded is entirely similar to that customary in a $24 \mathrm{hr}$. microculture on nutrient agar at $20^{\circ}$. In the latter case it is often difficult to obtain such a clear stationary picture when there is any film of moisture round the cells, since considerable numbers of the shorter cells exhibit varying degrees of motility as soon as a coverslip is placed over the growth.

\section{Effect of humidity}

Other things being equal, a saturated aqueous environment promoted early subdivision of the cells into rods and filaments of varying lengths which tended to maintain their dimensions on multiplication (Pl. 1, fig. 3), while under arid conditions cell division proceeded to the extreme limits (Pl. 1, fig. 4). This 
difference was frequently observed between dry and moist agar mass cultures on the one hand; or in more detail where one set of cellophan microcultures was kept saturated for 10-14 days at room temperature, while the duplicates (in similar close-fitting slide boxes, lined with moistened wadding) were allowed to stand untended until the end of the experiment. A further factor is probably introduced in the latter instance as the result of the decreasing supply of nutrients diffusing through the drying membrane.

\section{Effect of surface tension}

As mentioned in Methods, the generally marked elongation of the cells is one of the main advantages of employing cellophan in microcultures. It seems probable that once a cell has begun to grow within the film of moisture surrounding a membrane and in a plane parallel to it, there is a strong opposing force against any upwards movement on the part of the cell away from the membrane. This can readily be demonstrated in micromanipulative practice by attempting to remove a relatively long filamentous cell away from a moistened cellophan surface by means of a microhook or loop. The resistance will be found to be considerable.

On the surface or in the immediate subsurface of solid gels such as $2 \%$ agar, Nocardia turbata develops a peripheral margin of comparatively long filaments or chains of cells, which may persist for weeks unfragmented, although the cell divisions are frequently clear. In slowly liquefying gelatin cultures the cells quickly divide into short rods and almost spherical coccoid forms, frequently with thickened cell walls (Pl. 1, fig. 5).

In the very small droplets of liquid broth delivered either by the spraying technique or by means of a micromanipulator, the detailed picture varied somewhat. Thus, it was a common occurrence to find that a single cell would elongate to a slight degree only, then divide by binary fission; the daughter cells would perhaps divide again or exhibit motility first, and not until four or five rods were present in the droplet would elongation and branching take place to produce a minute mycelium. In general, the shallower and smaller the drop the more filamentous the growth; so that in more convex droplets on the same slide cell division usually proceeded further with the production of a larger number of short cell elements. On the other hand, when one cell only was placed in a relatively large volume of broth $(0.5 \mathrm{ml}$. in a small tube) and the culture grown without shaking, a characteristic actinomycete type of growth resulted, namely a coherent mycelial complex of cells in a clear medium (see Erikson \& Masson, 1954). Fragmentation followed at least a day later, and in these circumstances it was clear that elongation and branching to some extent preceded or kept abreast of cell division.

When surface-active agents such as Tween 80 were added to liquid cultures ( $2 \mathrm{ml}$. volume), the chief result was a rapidly increased rate of cell division with a resultant predominance of small coccoid forms. Such very short elements rarely displayed more than Brownian motion. Larger pyriform cells, similar to that portrayed at the end of a filamentous branch in Pl. 2, fig. 13, were frequently found, especially in older cultures. 


\section{Effect of ageing of cultures}

The unknown changes which take place in complex media like nutrient broth as the result of profuse nocardial growth are probably attributable to both physical and chemical processes. They will include depletion and alteration of nutrients, altered $\mathrm{pH}$ value, appearance of metabolic and autolytic products. Seitz filtrates of old culture fluids, and of aqueous suspensions of old cells which had been allowed to autolyse for $2-3$ weeks at $37^{\circ}$, were added to young cultures in varying proportions, but failed to induce any marked acceleration of cell division. Nor were positive results obtained by altering the $\mathrm{pH}$ value within the range permissible to growth. In general, ageing was always accompanied by subdivision into shorter cells, but the time of onset and degree of subdivision depended upon the nature of the medium and other environmental factors.

In the following two sections chemical factors capable of influencing growth in the simpler media are considered.

\section{Effect of nature of carbon compound in the media}

The addition of polysaccharides such as starch and glycogen constantly favoured the production of a filamentous mycelium and inhibited to a considerable extent the process of cell division and onset of fragmentation. Thus, in a glycogen + nitrate liquid medium a granular bottom growth occurred which left the supernatant medium clear, the growth consisting almost entirely of comparatively long filamentous cells, all non-motile.

Among the simple sugars glucose was the only one which consistently induced a similar persistently filamentous growth. In a series of experiments in which various sugars were added to a basal ammonium phosphate medium, it was found that the proportion of long cells obtaining after 2 weeks of incubation was roughly comparable with glucose, starch, or glycogen and much higher than with galactose, lactose, fructose, sucrose, mannose, sorbose, arabinose, melezitose, xylose, raffinose, rhamnose, mannitol, dulcitol, sorbitol or glycerol.

Although glucose was readily fermented (lowering the $\mathrm{pH}$ value to $5 \cdot 0$ within 7 days), this was in varying degrees also the case with galactose, lactose, maltose, sucrose, xylose, arabinose, glycerol, or starch, especially in a casein hydrolysate basal medium. A comparative examination of the growths obtained with different carbon sources added to the four defined basal media made it clear that the $\mathrm{pH}$ value alone was not a decisive factor in the acceleration or retardation of cell division. Nor did there seem to be any relationship between $\mathrm{pH}$ value and the occurrence of motility, which was evident and sustained in presence of galactose, but not with mannose, fructose, or raffinose.

\section{Effect of nitrogen source used}

In general, the use of the media containing nitrate as nitrogen source resulted in a relatively small amount of growth which consisted initially of a high proportion of mycelial complexes later fragmenting into very short 
rods and coccoid cells that were non-motile (Pl. 1, fig. 4). When surface-active agents (e.g. Nonex 139) were added, the coccoid nature of the cell elements was greatly emphasized.

The media containing ammonium ion as nitrogen source supported a more profuse growth in which the mycelial phase was very transient and the predominant cell elements were rods of varying lengths. Long rods, often showing a subdivision into four or eight component cells (Pl. 1, fig. 9), were a feature of ammonium sulphate cultures. Paired cells, frequently motile, were very common in the ammonium chloride and ammonium phosphate cultures. On the whole, branching was less evident in the ammonium than in the nitrate media.

The tendency to grow and multiply almost exclusively in the form of short bacterium-like rods, with a partial or even complete submergence of the branched mycelial phase, became more marked in the case of media which contained those single amino acids that were capable of supporting good growth. Thus, Pl. 1, fig. 6, illustrates the short regular rods, often actively motile, in a 4-day culture in galactose + glutamate medium. Similar more or less uniform rods were obtained with glutamic acid, proline, glycine, alanine, arginine or asparagine as sole nitrogen source; very much shorter cells and generally poorer growth occurred with cystine, valine, methionine, leucine, tryptophan or aspartic acid; very slight or no growth occurred with lysine. The addition of glucose to those amino acids which supported only fair growth, e.g. aspartic acid, resulted usually in the production of a fair proportion of long filaments which showed little or no branching and which were non-motile.

A mixture of short and long rods and filaments, but exhibiting on the whole very little branching (Pl. 1, fig. 3), was yielded by growth in the complex of amino acids of an acid hydrolysate of casein. The addition of glucose tended to prolong the mycelial filamentous stage and to retard cell division, as compared with parallel sets of cultures containing galactose. With a massive inoculum galactose + casein hydrolysate cultures maintained a more or less stable equilibrium, with a predominance of rod forms, many of them motile, for relatively long periods of time, e.g. 3-4 weeks in a stoppered $100 \mathrm{ml}$. bottle. With the complex nitrogenous media growth was so abundant and the sequence of events so telescoped that it was possible to find almost all the stages recently described in a single $24 \mathrm{hr}$. culture on nutrient agar (see Pl. 2, fig. 10-18).

\section{DISCUSSION}

The dense opaque bodies noted by many workers as occurring in species of Nocardia were found in $N$. turbata in similar positions: at the poles of cells (Pl. 1, fig. 8; Pl. 2, fig. 18), and more or less evenly distributed along the course of fragmenting filaments (Pl. 2, figs. 10, 11, 15 and 17). Like McClung (1950), to whose paper reference should be made for a clear and critical account of these phenomena, I have been unable to determine the role, if any, played by such bodies in cell division. With the best optical system in the phase-contrast microscope, living cells about to divide appeared as a rule as dense as the two filaments shown in the electron micrograph of Pl. 2, fig. 14. 
Confirmation was obtained of the persistence of fine extensions of the cell wall after the separation of the cytoplasmic contents (Pl. 2, figs. 11, 15 and 16). This was the case whether the cells were photographed in situ on the membrane on which they were grown (Pl. 2, fig. 11), or whether they were removed by washing from the substrate on which they had grown (Pl. 2, fig. 16). On the other hand, there appear to be clear-cut cross walls in Pl. 2, fig. 10, which is another portion of the specimen shown in Pl. 2, figs. 11 and 13. However, when the cells at the growing tips of the filaments in these three pictures are carefully examined, the inequalities in diameter reveal a preliminary separation of the cytoplasmic contents, and it seems probable, as suggested by McClung, that the rupture of the outer wall occurs subsequently. The delicacy and elasticity of the outer cell wall was very evident throughout the studies of the living forms. In Pl. 1, fig. 3, for example, can be seen several spirally twisted cells which had just been moving; while in the lower chain of cells in Pl. 1, fig. 9, only two of the cells are in focus because of the slight spiral motion.

In concluding the account of the plasticity of cell forms in Nocardia turbata, their variety may be recapitulated as follows: on germinating short cells elongate, then according to environmental conditions (medium composition, temperature, liquid or solid culture, air supply, etc.) they may divide or branch, spin, rotate on their axes, swim, or form small or large complexes, which in turn may cohere for some time or fragment almost immediately; the branches may be motionless or actively motile in short cell, rod, filament, or 2-, 3- or 5-branched stages; and any one of these cell forms can give rise to the normal development again, but some factors (physical or chemical) favour, extend, accelerate, or retard one phase at the expense of the others.

Diagnostic description of Nocardia turbata n.sp.

Morphologically, the organism is a typical Gram-positive actinomycete, producing a small mycelium composed of slender filaments $(0 \cdot 1 \mu$ average diameter), which fragments into rods and coccoid cells. Many cells are motile under appropriate conditions; filamentous and rod-shaped cells weakly refractile; cocci in older cultures more strongly refractile. Non-acid-fast.

Aerobic. Optimum temperature 20-30 . Good growth on media such as nutrient (peptone + Marmite or Lab Lemco) agar. Colonies small, 0·1-2.0 $\mathrm{mm}$. diameter, taking 3-4 weeks to grow to full size. Growth initially colourless, producing a yellow-green pigment in 2-4 days on thickly sown slopes of nutrient agar. Pigment production favoured by a free air supply, suppressed by acid $\mathrm{pH}$ values. Individual colonies may retain filamentous margins for prolonged periods. Young broth cultures turbid, with subsequent sedimentation of the cells, pellicle formation, and eventual clarity of the medium (4-6 weeks).

Acid without gas produced within 7 days from glucose, sucrose, maltose, lactose, galactose, xylose, arabinose, glycerol, starch; not from mannitol, raffinose, rhamnose, sorbitol, dulcitol (using a casein hydrolysate basal medium). Nitrate nitrogen utilized. Gelatin not hydrolysed except in the 
presence of peptone, and then only slowly (3-6 weeks). Paraffin not a suitable source of energy.

Habitat. Probably soil.

The type culture is maintained in the Collection of the State Serum Institute, Copenhagen, Denmark.

This work was done by the author as a member of the scientific staff of the Agricultural Research Council. I wish to thank Prof. J. Cruickshank, C.B.E., for the hospitality of his department; Mr Gard of the University of Aberdeen for taking the electron micrographs; and Miss Mildred MacKay for technical assistance.

\section{REFERENCES}

Bergey's Manual of Determinative Bacteriology, (1948). 6th ed. Ed. Breed, R. S., Murray, E. G. D. \& Hitchens, A. P. Baltimore: Williams \& Wilkins Co.

Erikson, D. (1940). Pathogenic anaerobes of the Actinomyces group. Spec. Rep. Ser. med. Res. Coun., Lond. no. 240.

ErIKson, D. (1947). Differentiation of the vegetative and sporogenous phases of the actinomycetes. 1. The lipid nature of the outer wall of the aerial mycelium. J. gen. Microbiol. $1,39$.

Erikson, D. (1949). The morphology, cytology, and taxonomy of the actinomycetes. Annu. Rev. Microbiol. 3, 23.

ERIKson, D. (1952). Temperature/growth relationships of a thermophilic actinomycete, Micromonospora vulgaris. J. gen. Microbiol. 6, 286.

EnIKson, D. \& Masson, F. M. (1954). Modifications of micromanipulative practice suitable for single cell isolation and cultivation of $(a)$ aerobic and transiently chain-forming, (b) lipophilic and (c) microaerophilic bacteria. J. gen. Microbiol. 11, 209.

Jensen, H. L. (1931). Contributions to our knowledge of the Actinomycetales. II. The definition and subdivision of the genus Actinomyces, etc. Proc. Linn. Soc., N.S.W. 56, 345.

Jensen, H. L. (1953). The genus Nocardia (or Proactinomyces) and its separation from other Actinomycetales, with some reflections on the phylogeny of the actinomycetes. Symposium-Actinomycetales, VIth Int. Cong. Microbiol. Rome, p. 69. Oxford: Blackwell Scientific Publications Ltd.

Lentze, F. A. (1938). Zur Bakteriologie und Vakzinetherapie der Actinomykose. Zbl. Bakt. (1. Orig.), 141, 21.

McClung, N. M. (1950). Morphological studies in the genus Nocardia. II. Cytological studies. J. Bact. 59, 589.

ØRskov, J. (1923). Investigations into the Morphology of the Ray Fungi. Copenhagen: Levin and Munksgaard.

Ørskov, J. (1938). Untersuchungen über Strahlenpilze reingezüchtet aus dänischen Erdproben. Zbl. Bakt. (2. Abt.) 98, 344.

Topping, L. (1937). The predominant micro-organisms in soils. I. Zbl. Bakt. (2. $A b t$.), 97, 289.

Turner-Graff, R. (1952). An effective use of Petri dishes for microcultures. J. gen. Microbiol. 7, 31.

Waksman, S. A. \& Henrici, A. T. (1943). The nomenclature and classification of the actinomycetes. J. Bact. 46, 337.

Webley, D. M. (1953). A simple method for producing microcultures in hanging drops with special reference to organisms utilizing oils. J. gen. Microbiol. 8, 66 . 


\section{EXPLANATION OF PLATES}

\section{Plate 1}

Fig. 1. Filamentous branched mycelial microcolonies, 1 day at $30^{\circ}$, on cellophan over nutrient agar. Phase contrast. ( $\times 300$.)

Fig. 2. Fragmentation of central cell-mass of mycelia, 4 days at $20^{\circ}$, on cellophan over soil extract agar. Phase contrast. $(\times 300$.)

Fig. 3. Long rods with little branching, several spirally twisted; shorter rods and coccoid cells, the latter mostly out of focus ; 8 days at $20^{\circ}$ in liquid casein hydrolysate medium. Phase contrast. $(\times 1080$. $)$

Fig. 4. Complete fragmentation into short cell elements, 10 days on cellophan over glucose Czapek agar; fixed with formalin, lightly stained with Nile blue. $(\times 1200$.)

Fig. 5. Very small coccoid forms with thickened walls, 6 weeks at room temperature, liquefied peptone + gelatin culture. Phase contrast. $(\times 2160$. $)$

Fig. 6. Short motile rods, 4 days at $20^{\circ}$, in galactose + glutamate medium. Phase contrast. $(\times 1800$.

Fig. 7. Fragmented individual cells washed off cellophan growth over nutrient agar, 6 days at $20^{\circ}$; branched cell at $(a)$ has dense polar body. Electron micrograph. $(\times 5700$.

Fig. 8. Enlargement of Fig. $7(a) .(\times 17,100$.

Fig. 9. Filament containing four cells, and another spirally twisted one below containing eight cells of which only two are in focus; 10 days at $20^{\circ}$ in glucose ammonium sulphate liquid medium. Phase contrast. $(\times 1440$.)

\section{Plate 2}

Fig. 10. Extensive chain formation showing dense bodies more or less evenly disposed along the length of the cells, and clear cross walls; $18 \mathrm{hr}$. at $30^{\circ}$, on collodion over cellophan over heart broth-casein digest agar. Electron micrograph. $(\times 8840$. $)$

Fig. 11. Another portion of the specimen in Fig. 10, showing at top thread-like elongation of cell wall after separation of cytoplasmic contents, a pyriform swollen cell in the centre at the end of a chain, and beyond it a V-shaped cell. $(\times 7820$.

Fig. 12. Another field in the same specimen, showing 'slipping' branching at nodal position of $V$-shaped cell, with parallel bundles of cells about to follow new orientation. $(\times 9000$.

Fig. 13. Another field in the same specimen, showing marked inequalities of diameter, with rounding up of cytoplasmic contents at growing tips and stretching of the cell wall; large pyriform cell in centre. $(\times 10,200$. $)$

Fig. 14. Two rods from portion of 'palisade formation', washed off cellophan over nutrient agar, 24 hr, at $20^{\circ}$. Electron micrograph. $(\times 26,250$. $)$

Fig. 15. Coccoid and very short rod-shaped cells in palisade and chain formation, showing intercellular connexions and occasionally dense polar bodies; washed off cellophan over nutrient agar, 6 days at $20^{\circ}$. Electron micrograph. $(\times 14,250$.

Fig. 16. Fine thread-like extension connecting two rod-shaped cells; washed off cellophan over nutrient agar, 6 days at $20^{\circ}$. Electron micrograph. $(\times 13,680$.

Fig. 17. Chains of older coccoid and short cell elements in which dense polar bodies are more clearly visible; washed off cellophan over nutrient agar 12 days at $20^{\circ}$. Electron micrograph. $(\times 13,680$. $)$

Fig. 18. Two slender cells cohering in Y-formation, each showing polar body; washed off cellophan over nutrient agar, 4 days at $20^{\circ}$. Electron micrograph. $(\times 19,500$.

(Received 14 April 1954) 
Journal of General Microbiology, Vol. 11, No. 2
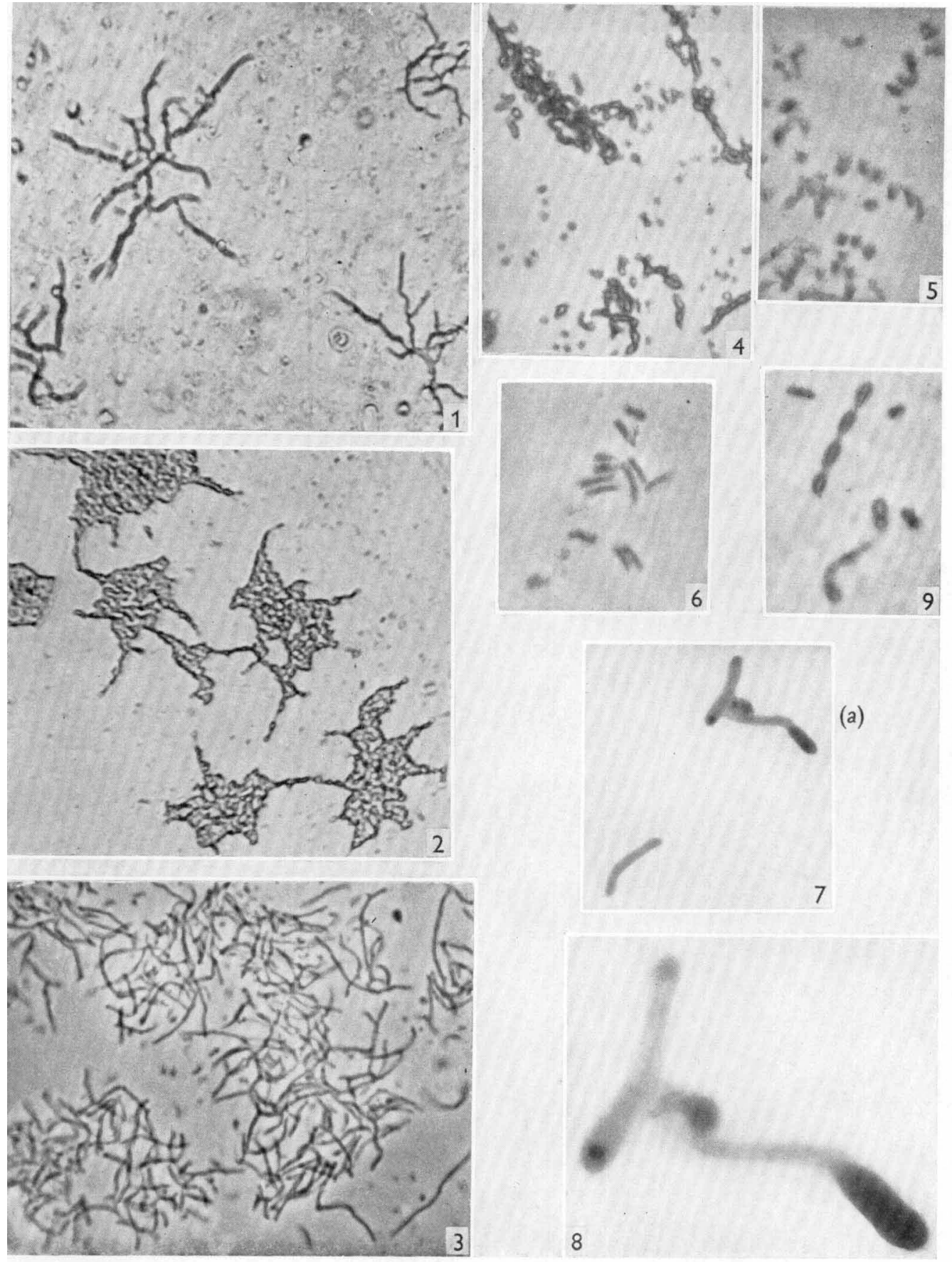

D. Erikson-Cell division in a 'soft' species of Nocarda. Plate 1 
Journal of General Microbiology, Vol. 11, No. 2

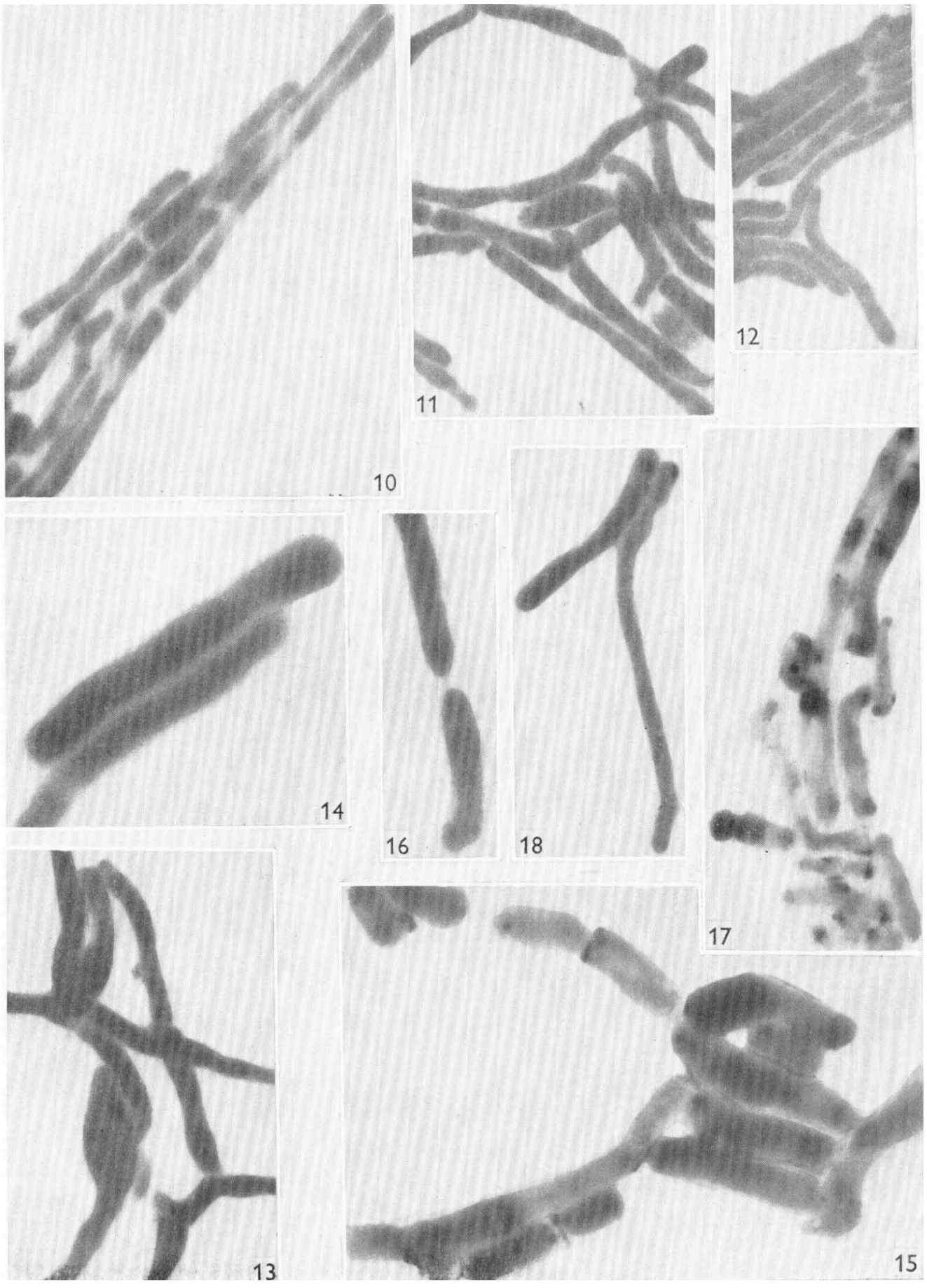

D. Erikson-Cell division in a 'soft' splectes of Nocardia. Plate 2 